\title{
Biochemical Composition and Isoenzymes of Enzyme Peroxidase of Houttuynia Cordata Thunb. from Brahmaputra Valley of Assam, India
}

\author{
N. Bhattacharyya ${ }^{1^{*}}$ and S. Sarma ${ }^{2}$ \\ ${ }^{1}$ Dept. of Botany, Nowgong College, Nagaon, Assam (782 001), India \\ ${ }^{2}$ Dept. of Biotechnology, Gauhati University, Guwahati, Assam (781 014), India
}

\section{Corresponding Author}

N. Bhattacharyya

e-mail:msnbhattacharyya@yahoo.co.uk

\author{
Article History \\ Manuscript No. AR1713b \\ Received in $20^{\text {th }}$ October, 2016 \\ Received in revised form $19^{\text {th }}$ May, 2017 \\ Accepted in final form $5^{\text {th }}$ June, 2017
}

\begin{abstract}
Houttuynia cordata Thunb. is a medicinal herb under the family Saururaceae, distributed in South-East Asia, mainly in China, Japan, Thailand and North-East India. In the present study, percentage of total chlorophyll, carotene and extractable essential oil were estimated in active growing season (April to July in 2008) in five different populations i.e. Nalbari (NL), Guwahati (GH), Nagaon (NG), Jorhat (JR) and Dhemaji $(\mathrm{DH})$ in the Brahmaputra valley of Assam. Average percentage of total chlorophyll, carotene and extractable essential oil were found to be $1.77 \%, 3.0 \%$ and $0.065 \%$ respectively. The simple linear curve fit of EO (\%) with chlorophyll (\%) and carotene (\%) had shown that the EO (\%) could be significantly related to the lowest chlorophyll (\%) and the highest carotenoid (\%) in the samples. A total of 28 components were identified by GC-MS analysis and the percentage of methyl nonyl ketone was the highest in all the five populations (33.722 \pm 1.261 ). Isoenzymes of enzyme peroxidase, present in $\mathrm{H}$. cordata were studied to know the molecular identity of the herb in the valley. The total numbers of isoenzymes were found to be six, which was comparable with that of Sichuan, China. There is no geographical variance, at least regarding the number of peroxidase isozymes present, in the $\mathrm{H}$. cordata plants collected from Jorhat district of Assam, North East India and that of Sichuan, China.
\end{abstract}

Keywords: Houttuynia cordata, chlorophyll, carotene, essential oil, isoenzymes, peroxidase

\section{Introduction}

Houttuynia cordata Thunb. is the single species in the genus and is native to Japan, South-East Asia and Himalayas. The systematic position of this plant is-division: Magnoliophyta, Class: Magnoliopsida, sub-class: Magnoliidae, order: Piperales, family: saururaceae (Watson \& Dallwitz, 1992). The creeping roots, young shoots and leaves of this aromatic medicinal herb have tremendous medicinal values and are traditionally used in various human diseases in entire South-East Asia. Flavonoids, exhibiting potential pharmacological activities, including antileukemic, antioxidative, antimutagenic, antiinflammatory, antiviral and immunomodulant function, are considered as one of the effective components in $\mathrm{H}$. cordata (Zhang et al., 2008). Reports confirmed the presence of 22 components in its essential oil, among which the most important were identified as $n$-Decanoic acid (11\%), $\alpha$-Terpineol (13\%), $\beta$-Myrcene (4\%), 1-decanol (4\%) and methyl nonyl ketone (35\%) (Lu et al., 2006). In an investigation on the effects of essential oils from $\mathrm{H}$. cordata Thunb as diet supplements on growth performance and immune responses of hybrid red tilapia, the essential oils was found to be a potential growth enhancer which could possibly replace antibiotics in enhancing fish immune response (Wigraiboon et al., 2016).

During the period of SARS outbreak, $H$. cordata was one of the ingredients in the SARS prevention formulae recognized by the Ministry of Public Health and the State Administrative Bureau of TCM (2003). The steam distillate of fresh $\mathrm{H}$. cordata was found to inhibit herpes simplex virus type-1 (HSV-1), influenza virus and human immunodeficiency virus type-1 (HIV-1) without showing cyto-toxicity (Hayashi et al., 1995). Isozymes (also known as isoenzymes) are enzymes that differ in amino acid sequence but catalyze the same chemical reaction. These enzymes usually display different kinetic parameters (i.e. different $\mathrm{K}_{\mathrm{M}}$ values), or different regulatory properties. The existence of isozymes permits the fine tuning of metabolism to meet the particular needs of a given tissue or developmental stage. In many cases isozymes are coded for by homologous genes that have diverged over time. Isozymes are usually the results of gene duplication, but can also arise from polyploidisation or nucleic acid hybridization (Hunter et al., 1957). Isozymes have been amongst the quickest, cheapest 
and the most widely used molecular markers for the study of population genetics. The basis of electrophoretic analysis of isozymes was laid down in 1957, when Hunter and Mohler discovered the isozymes.

Peroxidases (E.C. number 1.11.1.x) are a large family of oxidoreductase class of enzymes which play a major role in four physiological processes: auxin catabolism, lignin formation, defense mechanisms against pathogens and some respiratory processes (Gaspar et al., 1982). The peroxidase and esterase isozymes of the germplasm resources of Houttuynia in Sichuan, China were analyzed by Wu et al. (2002) and they found ample enzyme variations among the germplasm resources of $H$. cordata in Sichuan, China. Their result showed that there were 4-6 different types of peroxidase isozyme bands and 10 different esterase isozyme bands in total and the number of peroxidase isozyme bands in Northern Sichuan was somewhat higher than that in Southern Sichuan, China (Wu et al., 2002). It was shown that the peroxidase isozyme band types had geographic differences.

Studies reveal that the environment and clay loam type of soils with maximum moisture and slightly acidic $\mathrm{pH}$ in the Brahmaputra Valley of Assam, India is highly favourable for the comfortable growth and thick stocking of $\mathrm{H}$. cordata (Bhattacharyya and Sarma, 2010). Therefore, we aimed to study, the band types of isoenzymes of enzyme peroxidase, found in $H$. cordata from the Brahmaputra valley of Assam, to see geographic differences, if any. Again, after reviewing relevant literatures on tremendous medicinal potential of the herb, we intended to study on biochemical composition including chlorophyll, carotene and extractable essential oil of the herb from the Brahmaputra Valley of Assam.

\section{Materials and Methods}

\subsection{Study site}

For the study of total chlorophyll, total carotene and extractable essential oil, five populations of $\mathrm{H}$. cordata were selected from five regions of Assam viz., [Guakuchi, Dist.-Nalbari, $26^{\circ}-27^{\circ} \mathrm{N}$ and $91^{\circ}-97^{\circ} \mathrm{E}(\mathrm{NL})$; Lankeswar, Dist -Guwahati, $26.21^{\circ} \mathrm{N}$ and $91.46^{\circ} \mathrm{E}(\mathrm{GH})$, Amolapatty, Dist.Nagaon, $26.21^{\circ} \mathrm{N}$ and $92.41^{\circ} \mathrm{E}$ (NG), Pulibor, Dist.-Jorhat, $26.44^{\circ} \mathrm{N}$ and $94.10^{\circ} \mathrm{E}$ (JR) and Sisibargaon, Dist.-Dhemaji, $27.29^{\circ}-27.48^{\circ} \mathrm{N}$ and $94.35^{\circ}-94.54^{\circ} \mathrm{E}(\mathrm{DH})$ ] (Figure 1). The study was done during the months of April to August, 2008.

For isoenzyme analysis of enzyme peroxidase, $H$. cordata were collected and studied from Jorhat $\left(26.44^{\circ} \mathrm{N}\right.$ and $\left.94.10^{\circ} \mathrm{E}\right)$ district of the Brahmaputra valley of Assam during the months of June to July in 2008. The site represents the upper part of the state of Assam. The soil of the site was slightly acidic $(\mathrm{pH} \approx 6)$, clay loam with high humidity (soil moisture $\approx 78 \%$ ).

\subsection{Total chlorophyll and carotene in natural condition}

The total chlorophyll and total carotene were estimated for five leaf samples collected from five different experimental sites (NL, GH, NG, JR and DH), by spectro-photometric technique,

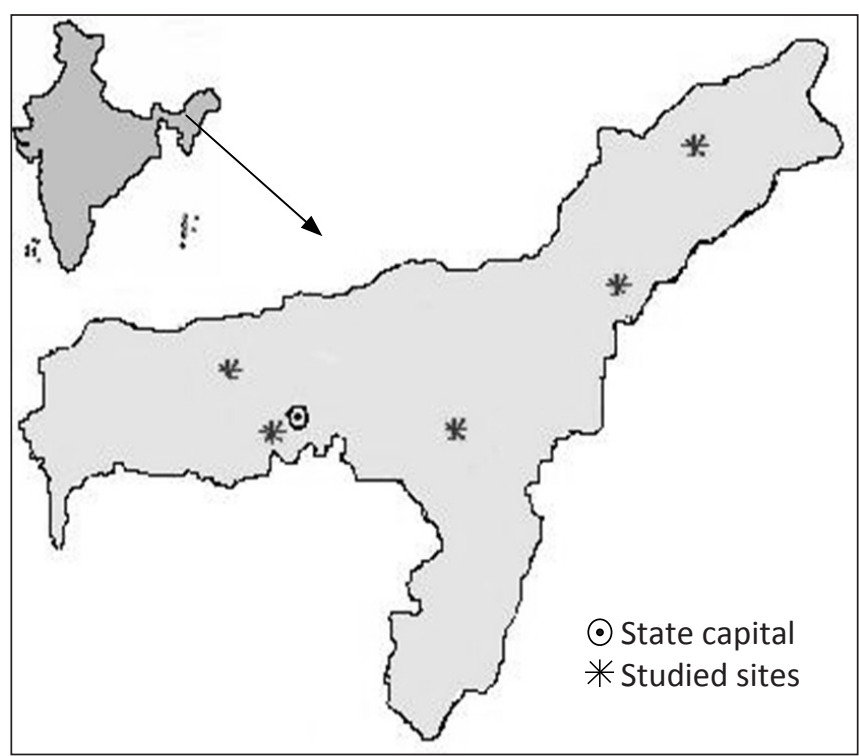

Figure 1: The locations of study area in the state of Assam in India

according to the methodology of Arnon (1949). Accordingly, $100 \mathrm{mg}$ of each leaf sample was weighed out and crushed in a mortar with $5 \mathrm{ml}$ of $90 \%$ acetone. The volume was adjusted up to $10 \mathrm{ml}$ and the extract was centrifuged. The supernatant was taken and subjected to spectro-photometry. The readings of absorption were taken against $90 \%$ acetone as blank in 490 $\mathrm{mm}, 644 \mathrm{~mm}$ and $663 \mathrm{~mm}$ wavelengths respectively. Then the readings were put in following equations to get the amount of total chlorophyll and total carotene.

Total Chl. $=\left[20.2\left(\mathrm{~A}_{645}\right)+8.02\left(\mathrm{~A}_{663}\right)\right] \times \mathrm{V} / 1000 \times \mathrm{W}(\mathrm{mg} / \mathrm{g})$

Total Carotene $=\left[\left(A_{490}\right)-(0.114)\left(A_{663}\right)-(0.638)\left(A_{645}\right)\right] \times V / 1000 \times W$ $\left(\mathrm{mg} \mathrm{g}^{-1}\right)$

2.3. Amount of extractable essential oil (EO) in natural condition

The essential oils of five samples of the herb, collected from five regions of Brahmaputra valley of Assam (NL, GH, NG, JR and $\mathrm{DH}$ ), were extracted according to the standard extracting method in Chinese Pharmacopoeia (Chinese Pharmacopoeia Committee, Publishing House of People's Health 2000, page appendix. 64). Accordingly $400 \mathrm{~g}$ of fresh herb along with distilled water were placed in Clevenger apparatus and subjected to hydro-distillation for $6 \mathrm{hrs}$ at $100^{\circ} \mathrm{C}$.

\subsection{GC-MS analysis of essential oil}

The major constituents of the essential oils were analyzed by GC and GC-MS. GC analysis was carried out on a Chemito 8510 GC instrument equipped with a data processor. A BP-5 wide-bore capillary column $\left(30 \times 0.53 \mathrm{~mm}^{2}\right.$ i.d., $1.0 \mu \mathrm{m}$ film thickness) was used for the separation of the sample components (sample size $0.03 \mu \mathrm{l}$, measured using a Hamilton GC syringe of $1.0 \mu \mathrm{l}$ cap.). Hydrogen was used as the carrier gas at a flow rate of $5 \mathrm{ml} \mathrm{min} \mathrm{m}^{-1}$ and 20 p.s.i. inlet pressure. The GC column oven temperature was from $70{ }^{\circ} \mathrm{C}$ to $210^{\circ} \mathrm{C}$ 
at a rate of $2.5^{\circ} \mathrm{C} \mathrm{min}-1$, with a final hold time of $5 \mathrm{~min}$. Both injector and detector (FID) temperatures were maintained at $230{ }^{\circ} \mathrm{C}$. GC-MS analysis was carried out on a Trace DSQ MS (Thermo Electron Corporation), using a BP-5 capillary column (30×0.25 $\mathrm{mm}^{2}$ i.d., $0.5 \mu \mathrm{m}$ film thickness); with helium as the carrier gas at a flow rate of $1 \mathrm{ml} \mathrm{min}^{-1}$; split ratio $1: 20$. The column temperature was from $65^{\circ} \mathrm{C}$ to $210{ }^{\circ} \mathrm{C}$ ( $10 \mathrm{~min}$ hold) at $3^{\circ} \mathrm{C} \mathrm{min}^{-1}$. Mass spectra were recorded in the range $50-450$ amu, operating at $70 \mathrm{eV}$, and the ion source temperature was maintained at $200{ }^{\circ} \mathrm{C}$. The constituents of the oil were identified by using standard reference compounds and also by matching the mass spectra fragmentation pattern with National Institute of Standards and Technology (NIST) Mass Spectra Library stored in the GC-MS database.

\subsection{Extraction of proteins from fresh leaves}

Protein was extracted according to the procedure of Baaziz et al. $(1989,1994)$ and $0.25 \mathrm{~g}$ of plant leaf was ground in $1.5 \mathrm{ml}$ of $5 \mathrm{mM}$ Tris- $\mathrm{HCl}$ buffer (pH 7.2), containing $0.25 \mathrm{M}$ sucrose and $1 \mathrm{mM} \mathrm{MgCl}_{2}$. The extract was then centrifuged at $9000 \mathrm{rpm}$ for $7 \mathrm{~min}$ at $4{ }^{\circ} \mathrm{C}$. The supernatant contained soluble enzyme fraction (S). The pellet was washed 3 times in $1.5 \mathrm{ml}$ of $5 \mathrm{mM}$ Tris- $\mathrm{HCl}$ buffer ( $\mathrm{pH} 7.2$ ) containing $1 \%(\mathrm{v} / \mathrm{v})$ Triton $\times 100$. The supernatant after quick spin contained the membrane bound protein fraction. Then the residue was incubated for $30 \mathrm{~min}$. in $1.5 \mathrm{ml}$ of $5 \mathrm{mM}$ Tris- $\mathrm{HCl}$ buffer $(\mathrm{pH}=7.2)$ containing $1 \mathrm{M}$ $\mathrm{NaCl}$. After incubation, centrifugation was done at $9000 \mathrm{rpm}$ for $7 \mathrm{~min}$ at $4{ }^{\circ} \mathrm{C}$. The supernatant contained the ionically wall bound enzyme fraction (I). All the fractions were then used for ammonium sulphate fractionation.

\subsection{Ammonium sulphate fractionation}

Solid ammonium sulphate was added to the crude extracts until $60 \%$ saturation and the slurry was stirred in ice bath to dissolve the salt completely. These salt saturated fractions were retained overnight at $4^{\circ} \mathrm{C}$. After that, centrifugation was done at $12000 \mathrm{rpm}$ for $10 \mathrm{~min}$ at $4{ }^{\circ} \mathrm{C}$. The precipitates were re-dissolved in a minimal volume of $5 \mathrm{mM}$ Tris- $\mathrm{HCl}$ buffer $(\mathrm{pH}$ 7.2). The preparation was desalted by the process of dialysis.

\subsection{Dialysis}

Dialysis of the re-dissolved protein was done against buffer containing $5 \mathrm{mM}$ Tris- $\mathrm{HCl}$ buffer $(\mathrm{pH} \mathrm{7.2)}$ and $1 \mathrm{mM} \mathrm{MgCl}$. Protein fractions were put inside a dialysis bag and the opened edges of the bag was sealed with clips. The bag was then kept in dialysis buffer $(2000 \mathrm{ml})$ for three hours to precede the dialysis process. The buffer was changed three times after every three hours. After dialysis, the protein fractions were subjected to Native-PAGE and SDS-PAGE respectively.

\subsection{Native-PAGE for acidic proteins}

Native-PAGE was carried out in a discontinuous buffer system in slab gel electrophoresis apparatus. The electrophoresis was carried out in $12 \%$ acryl amide gel. The resolving gel contained Tris- $\mathrm{HCl}$ buffer ( $\mathrm{pH} 8.8$ ). The running buffer was containing $0.02 \mathrm{M}$ Tris-0.2 M glycine, ( $\mathrm{pH} 8.3)$. The protein was mixed with equal volume of loading buffer containing $50 \mathrm{mM}$ Tris-Cl (pH 6.8), 0.1\% bromophenol blue, and 10\% glycerol.
After electrophoresis (at 100V), the electrophorogram was incubated for activity staining.

\subsection{Native-PAGE for basic proteins}

In Native-PAGE, the native state of the proteins are maintained to study the activity of the protein. No denaturant (for example, SDS) is used in the process and the whole process is performed at $4{ }^{\circ} \mathrm{C}$ to avoid the loss of activity of the enzyme and degradation due to protease activity.

The electrophoresis was carried out in 12\% acryl amide gel. The resolving gel ( $\mathrm{pH} 4.3$ ), contained $0.06 \mathrm{M} \mathrm{KOH}$ and 0.375 $\mathrm{M}$ acetic acid. The running buffer $(\mathrm{pH} 4.5)$ contained $0.35 \mathrm{M}$ $\mathrm{b}$-alanine and $0.14 \mathrm{M}$ acetic acid. The protein was mixed with equal volume of loading buffer, containing $50 \mathrm{mM}$ Tris-Cl (pH 6.8), $0.1 \%$ bromophenol blue and $10 \%$ glycerol. All the processes were done at $4{ }^{\circ} \mathrm{C}$. After electrophoresis (at 100 $\mathrm{V})$, the electrophorogram was incubated for activity staining.

\subsection{Activity staining for enzyme peroxidase}

After electrophoresis, the gel was incubated for activity staining in $10 \mathrm{ml}$ of $0.1 \mathrm{M}$ acetate buffer $(\mathrm{pH}=5.0)$, containing $0.1 \%(\mathrm{~W} / \mathrm{V})$ benzidine and $0.01 \% \mathrm{H}_{2} \mathrm{O}_{2}$.

\section{Results and Discussion}

\subsection{Variation in essential oil, chlorophyll and carotene} percentage

The percentage of EO, extracted from five samples varied from $0.060 \% \pm 0.0061(\mathrm{GH})$ to $0.075 \% \pm 0.0062(\mathrm{JR})$, with an average of $0.065 \% \pm 0.0060$ [CD $=0.0072]$. The chlorophyll content varied from $0.156 \% \pm 0.020$ to $0.194 \% \pm 0.017$ with an average of $0.178 \pm 0.016[C D=0.0194]$; while the carotenoid content varied from $0.027 \% \pm 0.0036$ to $0.036 \% \pm 0.0037$ with an average of $0.030 \pm 0.0037$ [CD=0.0046] (Table 1). It was found that the EO percentage was the maximum in the sample of JR, where the chlorophyll (\%) and carotenoid (\%) were the minimum and the maximum, respectively. It was found that the chlorophyll percentage is inversely proportionate to extractable oil percentage. The simple linear curve fit of EO

Table 1: Different growth and bio-chemicals parameters of H. cordata

\begin{tabular}{lccc}
\hline $\begin{array}{l}\text { Studied } \\
\text { sites }\end{array}$ & $\begin{array}{c}\text { \% of essen- } \\
\text { tial oil }\end{array}$ & $\begin{array}{c}\text { \% of total } \\
\text { chlorophyll }\end{array}$ & $\begin{array}{c}\% \text { of total } \\
\text { carotenoid }\end{array}$ \\
\hline $\mathrm{NL}$ & $0.065 \pm 0.0056$ & $0.168 \pm 0.016$ & $0.031 \pm 0.0035$ \\
$\mathrm{GH}$ & $0.060 \pm 0.0061$ & $0.194 \pm 0.017$ & $0.027 \pm 0.0036$ \\
$\mathrm{NG}$ & $0.062 \pm 0.0058$ & $0.188 \pm 0.017$ & $0.028 \pm 0.0029$ \\
$\mathrm{JR}$ & $0.075 \pm 0.0062$ & $0.156 \pm 0.020$ & $0.036 \pm 0.0037$ \\
$\mathrm{DH}$ & $0.065 \pm 0.0060$ & $0.184 \pm 0.016$ & $0.028 \pm 0.0030$ \\
Mean & $0.065 \pm 0.0060$ & $0.178 \pm 0.016$ & $0.030 \pm 0.0037$ \\
$\mathrm{SEm} \pm$ & 0.00258 & 0.00699 & 0.00164 \\
$\mathrm{CD}(p=0.05)$ & 0.0072 & 0.0194 & 0.0046 \\
\hline
\end{tabular}

SE: Standard error mean; CD: Critical difference at $(95 \%$ confidence level) 
(\%) with chlorophyll (\%) ( $\left.\mathrm{R}^{2}=0.75597\right)$ (Figure 2$)$ and carotene (\%) $\left(R^{2}=0.96887\right)$ (Figure 3$)$ had shown that the EO (\%) could be significantly related to the lowest chlorophyll (\%) and the highest carotenoid (\%) in the samples. (Table 1)

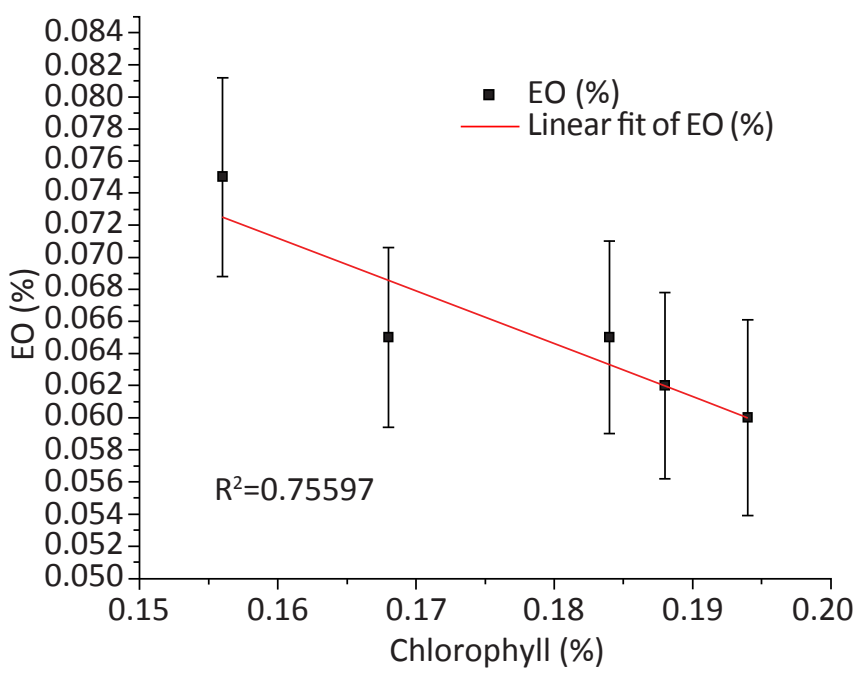

Figure 2: Simple linear curve fit of chlorophyll (\%) with EO (\%)

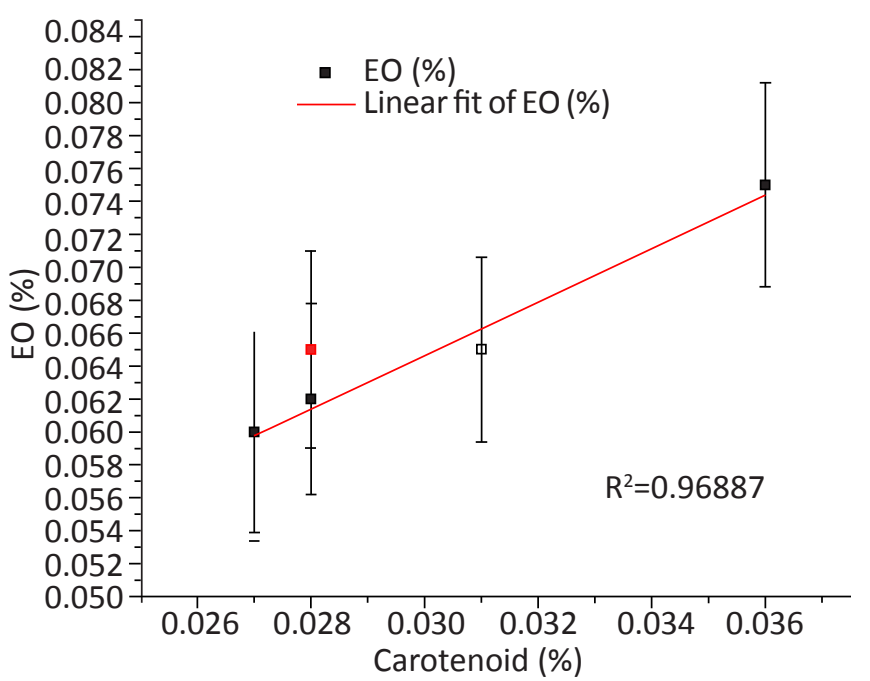

Figure 3: Simple linear curve fit of carotenoid (\%) with EO (\%) However, the overall ANOVA showed no significant variation $(p>0.05)$ of EO (\%), chlorophyll (\%) and carotenoid (\%) among all the five populations of Assam (Table 2, 3, 4)

\subsection{Phyto-constituents of essential oils}

The major constituents of the essential oil are shown in Table 5. A total of 28 components were identified and the major components were $\beta$-myrcene $(11.94 \% \pm 1.661)$, trans- $\beta$-ocimene $(1.844 \% \pm 0.223)$, $n$-decanal $(3.676 \% \pm 0.604)$, Decanol $(2.908 \% \pm 0.270)$, Methyl nonyl ketone/2-undecanone (33.722\% \pm 1.261$)$, Bornyl acetate $(7.328 \% \pm 1.061), n$-decanoic acid (3.376\% \pm 0.499$)$, acetic acid geraniol ester $(6.036 \% \pm 1.127)$, 3-Methylene-undecane (1.648\% \pm 0.307$), 2$-Dodecanone $(1.2825 \% \pm 0.392)$, Caryophyllene $(2.274 \% \pm 0.389)$, 4-Tridecanone (3.562\% \pm 0.330$)$, Docosanoic acid ethyl ester
Table 2: Overall ANOVA (at 0.05 levels) of percentage of essential oil of $H$. cordata in five different sites of Assam

\begin{tabular}{lccccc}
\hline & DF & SS & MS & F Value & Prob $>F$ \\
\hline Model & 4 & $4.00 \mathrm{E}-04$ & $9.99 \mathrm{E}-05$ & 2.95562 & 0.07494 \\
Error & 10 & $3.38 \mathrm{E}-04$ & $3.38 \mathrm{E}-05$ & & \\
Total & 14 & $7.38 \mathrm{E}-04$ & & & \\
${ }^{*} p>0.05$ & & & & &
\end{tabular}

Table 3: Overall ANOVA (at 0.05 levels) of chlorophyll percentage of $H$. cordata in five different sites of Assam

\begin{tabular}{lccccc}
\hline & DF & SS & MS & F Value & Prob $>F$ \\
\hline Model & 4 & 0.2928 & 0.0732 & 2.47215 & 0.11202 \\
Error & 10 & 0.2961 & 0.02961 & & \\
Total & 14 & 0.5889 & & & \\
\hline${ }^{*} p>0.05$ & & & & & \\
& & & & & \\
\hline
\end{tabular}

Table 4: Overall ANOVA (at 0.05 levels) of carotenoid percentage of $H$. cordata in five different sites of Assam

\begin{tabular}{lccccc}
\hline & DF & SS & MS & F Value & Prob $>F$ \\
\hline Model & 4 & 1.08 & 0.27 & 1.19872 & 0.41403 \\
Error & 5 & 1.1262 & 0.22524 & & \\
Total & 9 & 2.2062 & & & \\
\hline${ }^{*} p>0.05$ & & & & &
\end{tabular}

$(5.318 \% \pm 0.642)$ etc. The percentage of methyl nonyl ketone was the highest in all the five populations (33.722 1 1.261), followed by $\beta$-Myrcene (11.94 \pm 1.661$)$. The compositions of $H$. cordata do not significantly vary from the other studies reported earlier (Hayashi et al., 1995; Lu et al., 2006; Liang et al., 2005; Qi et al., 2004; Zeng et al., 2003, 2005; Meng et al., 2005a, 2005b; Dai et al., 2015). However, the amount of the major components varied from another study from Vietnam (Dai et al., 2015), where they found the amount of $\beta$-Myrcene to be the highest (30.8\%), followed by 2 -undecanone (19.7\%).

Previous studies reported that the current $H$. cordata was the relic of its agamic race (Liang, 1995). H. cordata populations exhibit high variations in chromosome number and at the nuclear genome level (Wu et al., 2003, 2005a, b, c). Therefore, the composition of the essential oil shows variations among H. cordata accessions (Chen et al., 2008).

\subsection{Native-PAGE for acidic and basic proteins (activity stain)}

The Native-PAGE of acidic protein, after activity staining with benzidine and hydrogen peroxide, showed 5 isozyme bands ( 1 , 2, 3, 4 and 5) in the lane loaded with soluble protein (Figure 4). No mobility shift was observed for the peroxidase in the lane number 2. However, in lane 3, 4 and 6 faint bands of peroxidase activity were seen.

The Native-PAGE of basic protein, after activity staining with 


\begin{tabular}{|c|c|c|c|c|c|c|c|}
\hline \multirow{2}{*}{$\begin{array}{l}\text { Com- } \\
\text { pounds } \\
\text { no. }\end{array}$} & \multicolumn{5}{|c|}{ Composition \% } & \multirow{2}{*}{$\begin{array}{l}\text { Aver- } \\
\text { age }\end{array}$} & \multirow[t]{2}{*}{ SD } \\
\hline & $\mathrm{NL}$ & GW & NG & $J R$ & $\mathrm{DH}$ & & \\
\hline 1. & $\operatorname{tr}$ & $\operatorname{tr}$ & $\operatorname{tr}$ & $\operatorname{tr}$ & $\operatorname{tr}$ & - & - \\
\hline 2. & 12.5 & 10.6 & 11.2 & 10.8 & 14.6 & 11.94 & 1.661 \\
\hline 3. & $\operatorname{tr}$ & $\operatorname{tr}$ & $\operatorname{tr}$ & $\operatorname{tr}$ & $\operatorname{tr}$ & & \\
\hline 4. & 2.02 & 1.6 & 2 & 1.6 & 2 & 1.844 & 0.223 \\
\hline 5. & $\operatorname{tr}$ & $\operatorname{tr}$ & $\operatorname{tr}$ & $\operatorname{tr}$ & $\operatorname{tr}$ & - & - \\
\hline 6. & $\operatorname{tr}$ & $\operatorname{tr}$ & $\operatorname{tr}$ & $\operatorname{tr}$ & $\operatorname{tr}$ & - & - \\
\hline 7. & $\operatorname{tr}$ & $\operatorname{tr}$ & $\operatorname{tr}$ & $\operatorname{tr}$ & $\operatorname{tr}$ & - & - \\
\hline 8. & $\operatorname{tr}$ & $\operatorname{tr}$ & $\operatorname{tr}$ & $\operatorname{tr}$ & $\operatorname{tr}$ & - & - \\
\hline 9. & $\operatorname{tr}$ & $\operatorname{tr}$ & $\operatorname{tr}$ & $\operatorname{tr}$ & $\operatorname{tr}$ & - & - \\
\hline 10. & 2.86 & 4.5 & 3.9 & 3.7 & 3.42 & 3.676 & 0.604 \\
\hline 11. & $\operatorname{tr}$ & $\operatorname{tr}$ & $\operatorname{tr}$ & 1.02 & $\operatorname{tr}$ & - & - \\
\hline 12. & 2.86 & 2.8 & 3.12 & 3.22 & 2.54 & 2.908 & 0.27 \\
\hline 13. & 32.86 & 32.69 & 34.5 & 32.96 & 35.6 & 33.722 & 1.261 \\
\hline 14. & 7.52 & 7.6 & 8.6 & 5.66 & 7.26 & 7.328 & 1.061 \\
\hline 15. & $\operatorname{tr}$ & $\operatorname{tr}$ & $\operatorname{tr}$ & $\operatorname{tr}$ & $\operatorname{tr}$ & - & - \\
\hline 16. & $\operatorname{tr}$ & $\operatorname{tr}$ & $\operatorname{tr}$ & $\operatorname{tr}$ & $\operatorname{tr}$ & - & - \\
\hline 17. & 2.86 & 3.55 & 3.96 & 3.66 & 2.85 & 3.376 & 0.499 \\
\hline 18. & 7.52 & 6.52 & 5.68 & 4.45 & 6.01 & 6.036 & 1.127 \\
\hline 19. & 2.01 & 1.22 & 1.52 & 1.86 & 1.63 & 1.648 & 0.307 \\
\hline 20. & 1.02 & 1.02 & 1.85 & $\operatorname{tr}$ & 1.24 & 1.2825 & 0.392 \\
\hline 21. & $\operatorname{tr}$ & $\operatorname{tr}$ & $\operatorname{tr}$ & $\operatorname{tr}$ & $\operatorname{tr}$ & - & - \\
\hline 22. & 2.86 & 1.86 & 2.02 & 2.42 & 2.21 & 2.274 & 0.389 \\
\hline 23. & 3.92 & 3.12 & 3.45 & 3.86 & 3.46 & 3.562 & 0.33 \\
\hline 24. & $\operatorname{tr}$ & $\operatorname{tr}$ & $\operatorname{tr}$ & $\operatorname{tr}$ & $\operatorname{tr}$ & - & - \\
\hline 25. & $\operatorname{tr}$ & $\operatorname{tr}$ & $\operatorname{tr}$ & $\operatorname{tr}$ & $\operatorname{tr}$ & - & - \\
\hline 26. & $\operatorname{tr}$ & $\operatorname{tr}$ & $\operatorname{tr}$ & $\operatorname{tr}$ & $\operatorname{tr}$ & - & - \\
\hline 27. & 6.23 & 5.23 & 4.65 & 4.82 & 5.66 & 5.318 & 0.642 \\
\hline 28. & $\operatorname{tr}$ & $\operatorname{tr}$ & $\operatorname{tr}$ & $\operatorname{tr}$ & $\operatorname{tr}$ & - & - \\
\hline
\end{tabular}

1: Camphene; 2: $\beta$-Myrcene; 3: D-Limonene; 4: Trans- $\beta$ Ocimene; 5: 2,6-Dimethyl-3,5,7-octatriene-2-ol; 6: Perillen; 7: 4,4,6,6-Tetramethyl-bicyclo [3.1.0] hex-2-ene; 8: Nonanol; 9: $\alpha$-Terpineol; 10: $\mathrm{n}$-Decanal; 11: trans-Pinocarvyl acetate; 12: Decanol; 13: Methyl nonyl ketone; 14: Bornyl acetate; 15: Undecanal; 16: $\alpha$-Cyclogeraniol acetate; 17 : n-Decanoic acid; 18: Acetic acid geraniol ester; 19: 3-Methyleneundecane; 20: 2-Dodecanone; 21: Lauraldehyde; 22: Caryophyllene; 23: 4-Tridecanone; 24: Phenylcarbamic acid, 9-bromononyl ester; 25: Tetradecanoic; 26: trans-Nerolidol; 27: Docosanoic acid, ethyl ester; 28: Caryophyllene oxide; ${ }^{*}$ Compounds $\leq 1 \%$ is marked as $\operatorname{tr}$ (trace)

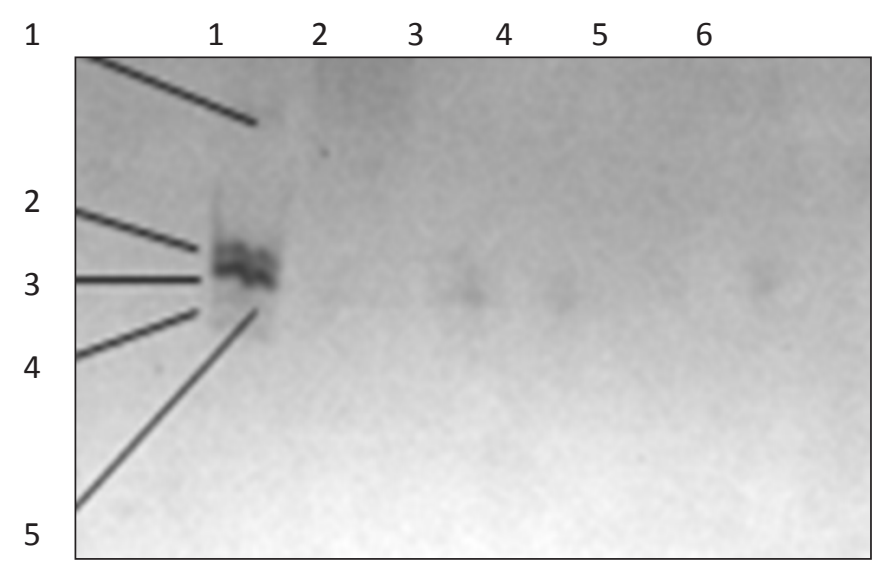

Figure 4: Native-PAGE for acidic proteins (activity stain); Lane: 1-Soluble protein [extracted with Tris-HCl buffer, $(\mathrm{pH} 7.2)+0.25$ $\mathrm{M}$ sucrose+1 mM MgCl2 ]; Lane: 2-lonically bound protein [5 $\mathrm{mM}$ Tris-HCl buffer ( $\mathrm{pH}$ 7.2)+1 M NaCl]; Lane: 3, 4, 5, 6-covalently bound protein [extracted with $5 \mathrm{mM}$ Tris- $\mathrm{HCl}$ buffer $(\mathrm{pH} 7.2)+1 \%(\mathrm{v} / \mathrm{v})$ Triton X 100].

benzidine and hydrogen peroxide, showed 1 isozyme band in each of lane numbers 2 and 4, loaded with covalently bound protein (Figure 5). In lane 6 (Soluble protein), a distinct band of peroxidase activity was seen. The results do not vary much from the results obtained by Wu et al. (2002). Thus it can be concluded that there is no geographical variance at least

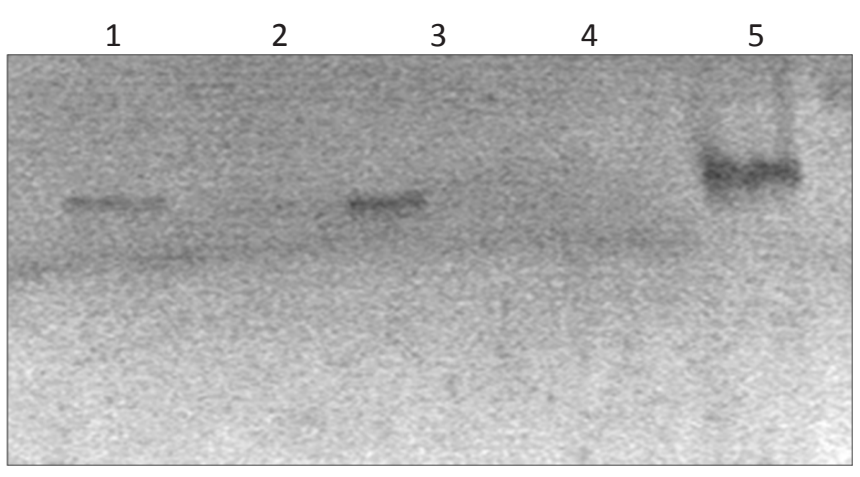

Figure 5: Native-PAGE for basic proteins (activity stain); Lane: 1, 2, 3-covalently bound protein [extracted with $5 \mathrm{mM}$ Tris$\mathrm{HCl}$ buffer $(\mathrm{pH}=7.2)+1 \%(\mathrm{v} / \mathrm{v})$ Triton $\times 100]$; Lane: 4-Ionically bound protein [ $5 \mathrm{mM}$ Tris- $\mathrm{HCl}$ buffer $(\mathrm{pH}=7.2)+1 \mathrm{M} \mathrm{NaCl}]$; Lane: 5-Soluble protein [extracted with Tris- $\mathrm{HCl}$ buffer, $(\mathrm{pH}$ 7.2)+0.25 M sucrose+1 mM MgCl${ }_{2}$ ]

regarding the number of peroxidase isozymes present in the $H$. cordata plants collected from Jorhat district of Assam, North East India and that of Sichuan, China. Population genetics deals with the genetic variation and transmission of hereditary information within populations of the nature (Boisselier-Dubayle et al., 1996) and genetic variability can be economically measured by enzyme electrophoresis. However, the plant height, biomass and growth performance of the plant were found to be varied significantly in five study sites of Assam, depending on the varied soil type, soil moisture and 
soil pH (Bhattacharyya and Sarma, 2010). Therefore, as a part of the follow up study, investigations can be done on the levels of electrophoretically detectable genetic variation among five populations of $H$. cordata in the Brahmaputra Valley of Assam, by studying the band patterns of peroxidase isozymes.

\section{Conclusion}

The results can help in identifying the populations with higher potential to yield essential oil of pharmaceutical importance. Populations with higher carotenoid content are more potential in this regard. Further investigation to elucidate the relation between higher carotenoid content and lower chlorophyll content with the yield of essential oil in the molecular basis is required. We suggest further studies in DNA level, using RAPD markers, to illustrate the genetic differences, if any, among the $H$. cordata populations of this region.

\section{Acknowledgement}

We are grateful to Prof. H.S. Savithri, Department of Biochemistry, I.I.Sc., Bangalore, for giving permission to conduct the experiments related to isoenzyme analysis part in her laboratory, during the Summer Research Fellowship programme, offered by Indian Academy of Sciences, Bangalore, 2008. We are also thankful to the analytical division of NEIST, Jorhat and Principal, Nowgong College, Nagaon, Assam, for the experiments related to essential oil composition and chlorophyll and carotenoid respectively.

\section{References}

Arnon, D.I., 1949. Copper enzyme in isolated chloroplasts polyphenol oxidase in Beta vulgaris. Plant Physiology Journal 24(1), 1-15.

Baaziz, M., Aissam, F., Brakez, Z., Bendiab, K., El Hadrami, I., Cheikh, R., 1994. Electrophoretic patterns of acid soluble proteins and active isoforms of peroxidase and polyphenoloxidase typifying calli and somatic embryos of two reputed date palm cultivars in Morocco. Euphytica 76(3), 159-168.

Baaziz, M., 1989. The activity and preliminary characterization of peroxidases in leaves of cultivars of date palm, Phoenix dactylifera L. New Phytologist 111, 403-411.

Bhattacharyya, N., Sarma, S., 2010. Assessment of availability, ecological feature and habitat preference of the medicinal herb Houttuynia cordata Thunb in the Brahmaputra valley of Assam, India. Environmental Monitoring and Assessment 160(1), 277-287.

Boisselier-Dubayle, M.C., Perreau-Bertrand, J., Lambourdiere, J., 1996. Genetic variability in wild populations of Mycena rosea. Mycological Research 100(6), 753-758.

Chen, L., Wu, W., Huang, C.Y., Yang, Y.X., Zheng, Y.L., 2008. Composition and variability of the essential oil of Houttuynia of China. Chemistry of Natural Compounds 44, 778-783.

Dai, D.N., Thang, T.D., Ogunmoye, A.R., Olanrewaju, I.E.,
Ogunwande, I.A., 2015. Chemical constituents of essential oils from the leaves of Tithonia diversifolia, Houttuynia cordata and Asarum glabrum grown in Vietnam American Journal of Essential Oils and Natural Products 2(4), 17-21.

Gaspar, T., 1982. Peroxidases: A survey of their biochemical and physiological roles in higher plants. Geneva University, Switzerland.

Hayashi, K., Kamiya, M., Hayashi, T., 1995. Virucidal effects of the stem distillate from Houttuynia cordata and its components on HSV-1, influenza virus and HIV. Planta Medica 61(3), 237-241.

Hunter, R.L., Merkert, C.L., 1957. Histochemical demonstration of enzymes separated by zone electrophoresis in starch gels. Science 125, $129-1295$.

Liang H.X., 1995. On the evolution and distribution in Saururaceae. Acta Botanica Yunnanica 17, 255-267.

Liang, M., Qi, M., Zhang, C., Zhou, S., Fu, R., Huang, J., 2005. Gas chromatography-mass spectrometry analysis of volatile compounds from Houttuynia cordata Thunb after extraction by solid-phase microextraction, flash evaporation and steam distillation. Analytica Chimica Acta 531, 97-104.

Lu, H.M., Liang, Y.Z., Yi, L.Z., Wu, X.J., 2006. Anti-inflammatory effect of Houttuynia cordata injection. Journal of Ethnopharmacology 104, 245-249.

Meng, J., Leung, K.S.Y., Jiang, Z., Dong, X., Zhao, Z., $2005 a$. Establishment of GC-MS fingerprint of fresh Houttuynia cordata. Chemical \& Pharmaceutical Bulletin 53(11), 1484-1489.

Meng, J., Leung, K.S.Y., Jiang, Z., Dong, X., Zhao, Z., Xu, L.J., 2005b. Establishment of HPLC-DAD-MS Fingerprint of Fresh Houttuynia cordata. Chemical \& Pharmaceutical Bulletin 53(12), 1604-1609.

Qi, M., Ge, X., Liang, M., Fu, R., 2004. Flash gas chromatography for analysis of volatile compounds from Houttuynia cordata Thunb. Analytica Chimica Acta 527, 69-72.

State Administrative Bureau of TCM (11 ${ }^{\text {th }}$ April, 2003): (http:// www.cntcm.com.cn/).

The Pharmacopoeia Committee of China, 2005. The Chinese Pharmacopoeia. The Chemical Industry Publishing House, Beijing, China, Vol.-I, 155.

Watson, L., Dallwitz, M.J., 1992. The families of flowering plants: description, illustrations, identification and information retrieval. Version: $8^{\text {th }}$ May 1998. URL http:// biodiversity.uno.edu/delta/.

Wigraiboon, S., Nomura, N.P., Whangchai, N., 2016. Effect of essential oils from Houttuynia cordata Thunb supplemented diets on growth performance and immune response of Hybrid red tilapia (Oreochromis mossambicus Linn.×Oreochromis niloticus Linn.). International Journal of Fisheries and Aquatic Studies 4(3), 677-684.

Wu, W., Zheng, Y., Chen, L., Yang, R., Yan, Z., Wei, Y., 2002. Isozymes variations among the germplasm resources of 
Houttuynia in Sichuan. Zhong Yao Cai 25 (10), 695-698.

Wu, W., Zheng, Y.L., Yang, R.W., Chen, L., Wei, Y.M., 2003. Variation of chromosome number and cytomixis of Houttuynia cordata Thunb. from China. Acta Phytotaxonomica Sinica 41, 245-257.

Wu, W., Zheng, Y.L., Chen, L., Wei, Y.M., Yan, Z.H., 2005a. Genetic diversity among the germplasm resources of the genus Houttuynia Thunb. in China based on RAMP markers. Genetic Resources and Crop Evolution 52, 473-482.

Wu, W., Zheng, Y.L., Chen, L., Wei, Y.M., Yan, Z.H., Yang, R.W., 2005b. PCR-RFLP analysis of cPDNA and mtDNA in the genus Houttuynia in some areas of China. Hereditas 142, 24-32.
Wu, W., Zheng, Y.L., Chen, L., Wei, Y.M., Yang, R.W., Yan, Z.H., 2005c. Evaluation of genetic relationships in the genus Houttuynia Thunb. in China based on RAPD and ISSR markers. Biochemical Systematics and Ecology 33, 1141-1157.

Zeng, Z., Shi, J.G., Zeng, H.P., Lai, W.L., 2003. Application of organic mass spectrometry in studies on Houttuynia cordata, a traditional Chinese medicine. Chinese Journal of Analytical Chemistry 31, 399-404.

Zhang, Y., Li, S., Wu, X., 2008. Pressurized liquid extraction of flavonoids from Houttuynia cordata Thunb. Separation and Purification Technology 58, 305-310. 